\title{
Helminth parasites of the African lizard Agama agama (Squamata: Agamidae), in Lagos, Nigeria
}

\author{
Adeoye, G.O. ${ }^{1} \&$ O.O. Ogunbanwo ${ }^{2}$ \\ 1 Department of Zoology, University of Lagos, Akoka, Yaba, Lagos, Nigeria; goa4567@yahoo.com \\ 2 Department of Zoology, University of Lagos, Akoka, Yaba, Lagos, Nigeria; godcatcher4@yahoo.com
}

Received 07-XII-2005. Corrected 27-VI-2006. Accepted 30-I-2007.

\begin{abstract}
Agama agama, the agamid rainbow lizard, has been reported to serve as transport and reservoir host to several protozoan and helminth parasites. We randomly sampled 310 specimens between May and July, 2005, at Oyingbo, Lagos, Nigeria (6³4'60" N-3 ${ }^{\circ} 19^{\prime} 59^{\prime \prime}$ E and 6 $34^{\prime} 60^{\prime \prime} \mathrm{N}-3^{\circ} 19^{\prime} 59^{\prime \prime}$ E). They harboured four species of nematodes: Strongyluris brevicaudata, Parapharyngodon awokoyai, Capillaria sp. and Oxyuris sp.; one of Cestoda, Oochoristica agamae; one of Trematoda, Mesocoelium monas; and one of Pentastomida, Raillietiella sp. Strongyluris brevicaudata had the highest prevalence of infection (82.3\%), followed by P. awokoyai (74.5 $\%)$, Raillietiella (10.3\%), Capillaria sp. (8.4\%) and O. agamae (7.4\%). M. monas and Oxyuris sp. had low prevalences: $1.61 \%$ each. Raillietiella sp. and Capillaria sp. can cause localized inflammation and intestinal infections in humans. The prevalence of infection was higher in larger adult lizards. Prevalence in males was $97.6 \%$ (94.1\% in females). In four of the helminth species, intensity of infection was higher in male lizards. Parasite intensity was highest in the rectum, followed by the intestine $(\mathrm{p}<0.05)$. Infection intensity was, to a large extent, dependent on the type of parasite, and age of lizard. During May, P. awokoyai had its highest mean intensities and prevalence. The prevalence and mean intensity of helminthes varied with the month of collection (both $\mathrm{p}<0.05$ ). For the three months studied, prevalence and mean intensity of $S$. brevicaudata were highest in June (July for the other species). Rev. Biol. Trop. 55 (2): 417-425. Epub 2007 June, 29.
\end{abstract}

Key words: intestinal helminthes, Agama agama, prevalence, intensity, Nigeria.

The agamid lizard Agama agama has been reported to serve as transport and reservoir host to several protozoan and helminth parasites (Wekhe and Olayinka 1999). In Nigeria, according to the investigations carried out by Babero and Okpala (1962), Akinboade (1981), and Wekhe and Olayinka (1999), Eimeria oocysts were the most prevalent $(68.7 \%$ ) protozoan parasites, followed by Plasmodium and Haemogregarina species. About $22 \%$ of wall geckos examined by Ameh and Ajayi (1996) were infected with gamonts of Lecudina, a gregarinid protozoan. Lecudina species were also recovered from the gut of termites found in the geckoes (Ameh and Ajayi 1996). Some of these parasites pose a risk to man, who can act as intermediate host. Man can be infected with Raillietiella sp. by having their hands contaminated from the faeces or saliva of the reptile, and accidentally ingesting the eggs (Nash 2005). Handling faecal contaminated water, dishes, and other equipment may also result in accidental transmission. Usually, there are no clinical signs; however, some people may develop localized inflammation. The larvae can encyst in various tissues, causing abdominal pain, vomiting, constipation, diarrhea, and a tender abdomen. In isolated cases, septicemia may occur (Nash 2005). Capillaria philippinensis causes human intestinal capillariasis. However, the lack of information on most helminths parasitizing lizards in Africa prevent us to better understand the relationship between these parasites and their hosts in Africa and 
also, possible hosts that can harbor species that potentially can infect man. The report of this study reveals different helminths parasitizing A. agama in Lagos, Nigeria.

\section{MATERIALS AND METHODS}

Study area: Lagos is one of the fastestgrowing cities in the world, and is located at $6^{\circ} 34^{\prime} 60^{\prime \prime} \mathrm{N}-3^{\circ} 19^{\prime} 59^{\prime \prime} \mathrm{E}$ and 6०34'60" N$3^{\circ} 19^{\prime} 59^{\prime}$ " E. Lagos is built on the mainland and the series of islands surrounding). Mean annual precipitation in Lagos is about 1900 To Abbreviated?mm. Temperatures throughout Nigeria are generally high; diurnal variations are more pronounced than seasonal ones. Highest temperatures occur during the dry season; rains moderate afternoon highs during the wet season. Average highs and lows for Lagos are $31{ }^{\circ} \mathrm{C}$ and $23{ }^{\circ} \mathrm{C}$ in January and $28^{\circ} \mathrm{C}$ and $23{ }^{\circ} \mathrm{C}$ in June. Mean temperatures recorded in Lagos for the months of May, June and July 2005 , were $29^{\circ} \mathrm{C}, 27^{\circ} \mathrm{C}$ and $25^{\circ} \mathrm{C}$ respectively (The Weather Underground Inc. 2006).

Collection and examination of samples: Three-hundred-and-ten (124 males and 186 females) lizards were pithed, dissected and had internal organs liver, intestine, caecum, heart, lung and stomach and the general cavity analized for the presence of any helminth. The size, (Snout-Vent with the gut Length, SVL) of 100 of the 310 lizards was taken. The organs were excised into different petri-dishes containing reptilian saline. Parasites found in the various organs were identified, counted and preserved in Formal Acetic Acid (FAA) and absolute alcohol separately. Trematodes and cestodes were stained in Gower's Carmine for $45 \mathrm{~min}$, washed in tap water, dehydrated through a graduated series of alcohol (50\%, 70 $\%, 90 \%, 100 \%$ ), cleared in xylene, mounted in Canada Balsam, and examined under the microscope. Fixed specimens of nematodes and pentastomes were simply cleared in lactophenol before examination under a microscope. Results were analysed using the Chi-Square
Test to find out the significance of the different associations were observed. In the present sudy the use of ecological terms in parasitology follows Bush et al. (1997).

\section{RESULTS}

Of the 124 males and 186 females examined, $121(97.6 \%)$ and $175(94.1 \%)$ were respectively infected with helminth parasites. A total of seven helminth species were recovered from different organs in the lizard. The helminth parasites found included four species of nematodes: Strongyluris brevicaudata was found in $82.3 \%$ of the lizards, Parapharyngodon awokoyai (74.5\%), Oxyuris sp. (1.6\%) and Capillaria sp. (8.4\%); one species of cestode, Oochoristica agamae (7.42\%); one species of trematode, Mesocoelium monas (1.6\%); and the pentastomids, Raillietiella sp. (10.3\%). Four out of the seven parasite species were found in the rectum. There were significant differences in the interactions between the parasite species and the organs in which they were found $(p<0.05)$. Overall parasite intensity was highest in the rectum, followed by the intestine. The highest number of worms found at once in the rectum was seventy-three (73), for only one species of parasite (S. brevicaudata). Oxyuris and Capillaria were both found in the stomach region and all the pentastomid species recovered were found in the lungs. Few worms were found in the lungs, but in one case, a total of 67 worms were found in the two lungs of a male lizard. The relationship between the intensity of infection and the organs infected was statistically significant $(p<0.05)$. The trematode species were found in the liver and in the rectum. No parasite was found in the heart.

Three of the seven parasites found, $S$. brevicaudata, Raillietiella and M. monas, had their highest prevalence and intensities in lizards within the size range of $13.0 \mathrm{~cm}$ and 13.9 $\mathrm{cm}$, as shown in Figures 1 and 2A, E and F. Highest intensity and prevalence of Capillaria were in lizards of SVL 12.0-12.9 cm, and 13.0$13.9 \mathrm{~cm}$, respectively (Fig. 1C, 2C). In Figure 


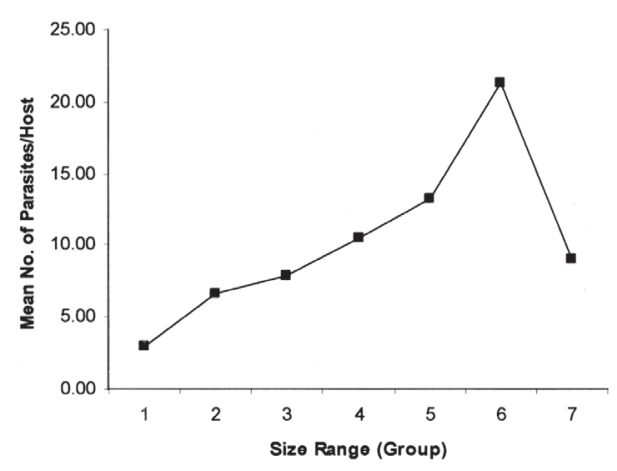

Fig. 1A. Mean Intensity of $S$. brevicaudata * Size.

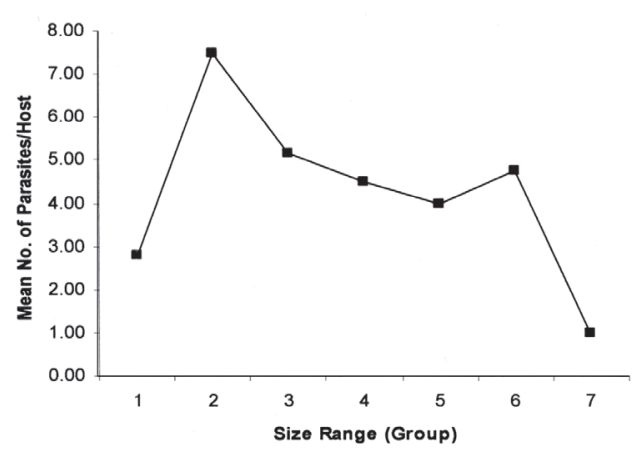

Fig. 1B. Mean Intensity of P. awokoyai * Size.

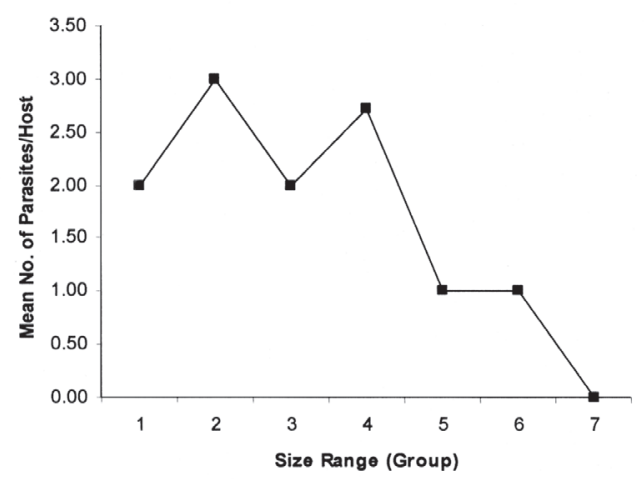

Fig. 1C. Mean Intensity of Capillaria * Size.

1B, the highest intensity of $P$. awokoyai, was recorded in lizards within size range of 12.0 $\mathrm{cm}$ and $12.9 \mathrm{~cm}$. O. agamae, Figure 1D, had its peak intensity in both adult female and male lizards $(9.0-9.9 \mathrm{~cm}$ and $13.0-13.9 \mathrm{~cm}$, respectively), and had its highest prevalence in younger lizards with SVL between 8.0-8.9 cm

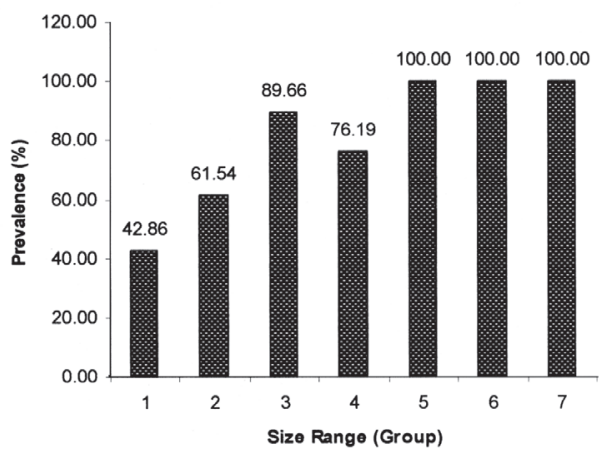

Fig. 2A. Prevalence of S. brevicaudata* Size.

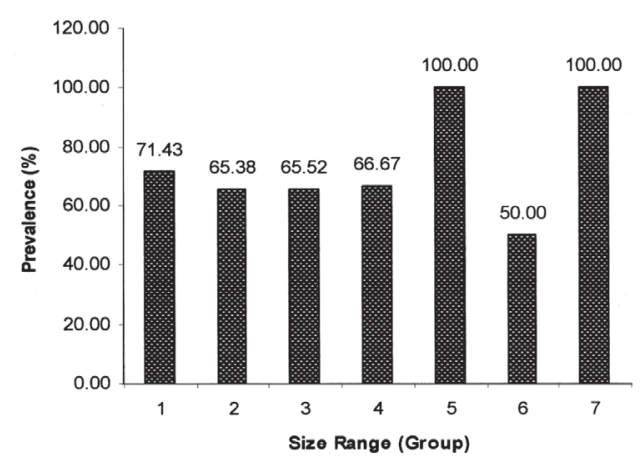

Fig. 2B. Prevalence of P. awokoyai * Size.

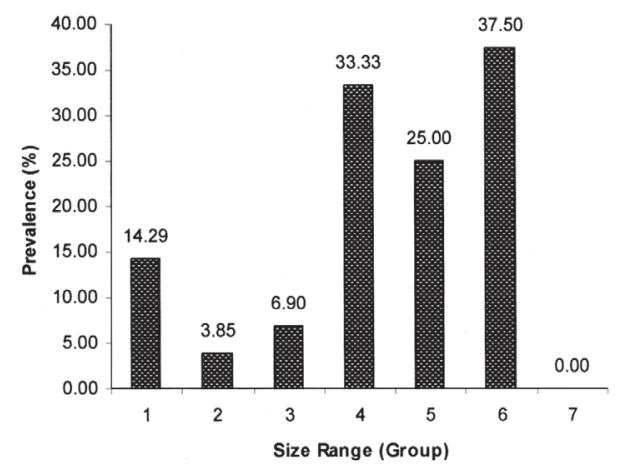

Fig. 2C. Prevalence of Capillaria* Size.

(Fig. 2D). Similar mean intensity of Oxyuris was found in all the size ranges in which they occurred (Fig. 1G). Both S. brevicaudata and $P$. awokoyai had their highest prevalences in adult lizards within the size range of 12.0-14.9 cm (Fig. 2A, B). The relationship between parasite intensity and the lizard length was positive 


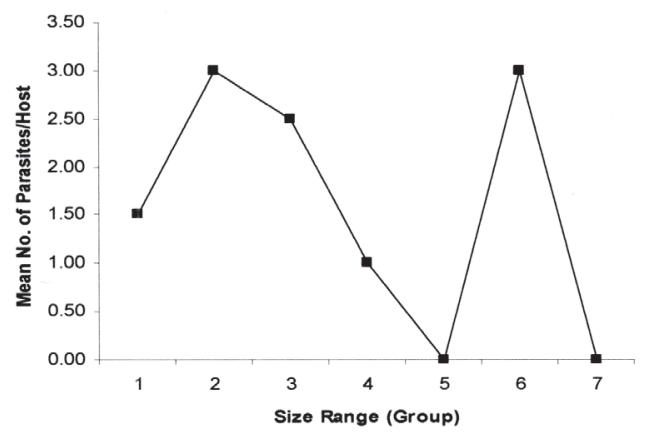

Fig. 1D. Mean Intensity of $O$. agamae* Size.

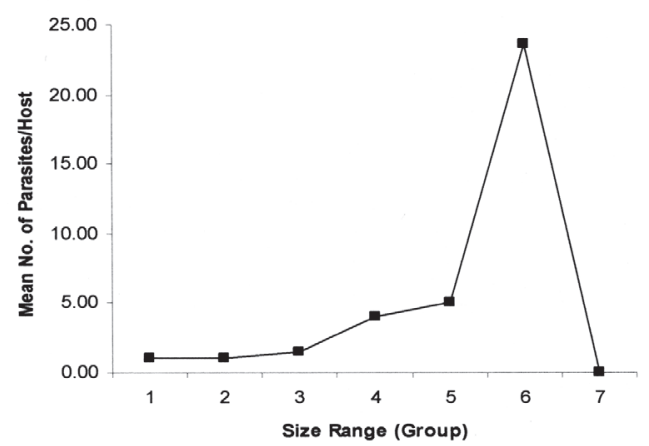

Fig. 1E. Mean Intensity of Raillietiella* Size.

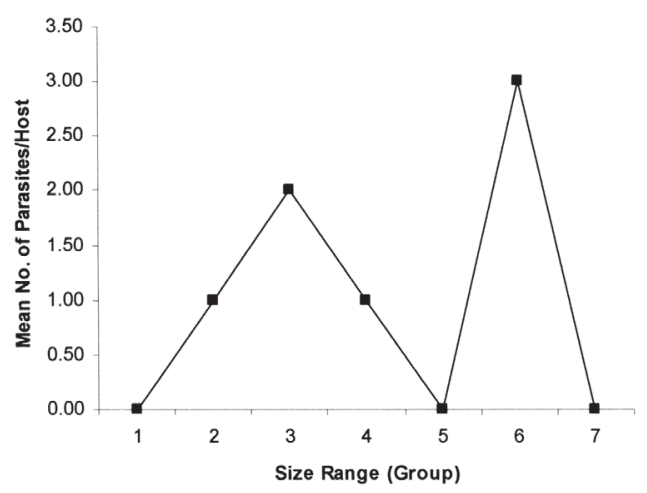

Fig. 1F. Mean Intensity of M. monodi * Size.

and significant $(\mathrm{p}<0.05)$; the number of parasites increases with the body size of lizards. However, there was no significant difference between the length of lizards and the species of parasites found infecting the lizards ( $>0.05)$.

S. brevicaudata had the highest prevalence of infection in both male and female lizards

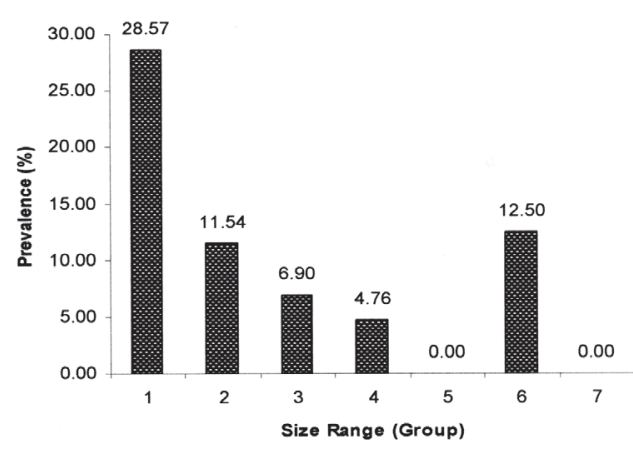

Fig. 2D. Prevalence of O. agamae* Size.

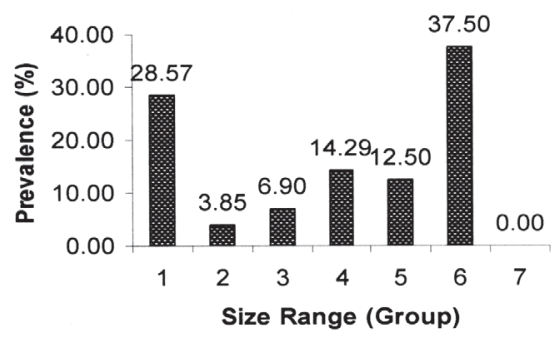

Fig. 2E. Prevalence of Raillietiella * Size.

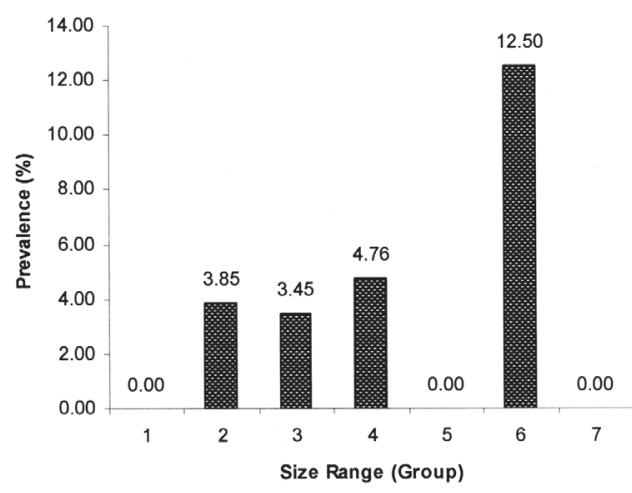

Fig. 2F. Prevalence of M. monodi * Size.

examined, $79.8 \%$ and $78.5 \%$ respectively (Fig. 3A). This was closely followed by P. awokoyai with $71.8 \%$ in male lizards and $75.3 \%$ in female lizards (Fig. 3A). Prevalence of $S$. brevicaudata and P. awokoyai were significantly higher in the lizards examined than those of other helminthes. Prevalence of P. awokoyai, 


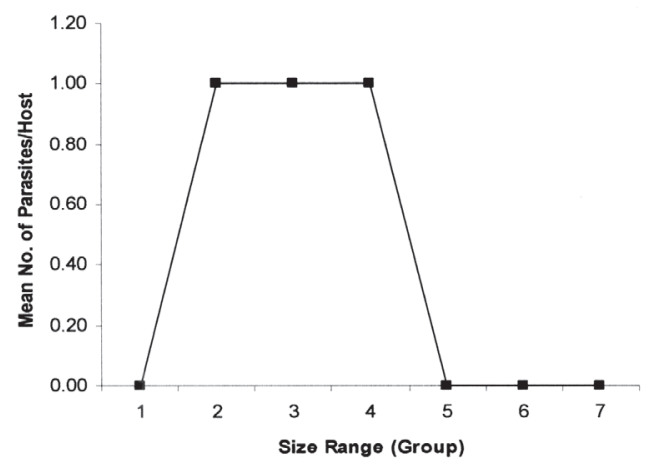

Fig. 1G. Mean Intensity of Oxyuris * Size.

O. agamae, M. monodi and Oxyuris sp. were higher in the female lizard than in the male lizard (Fig. 3A). S. brevicaudata, Raillietiella sp., and M. monas had higher intensities of infection in males than in females, in contrast

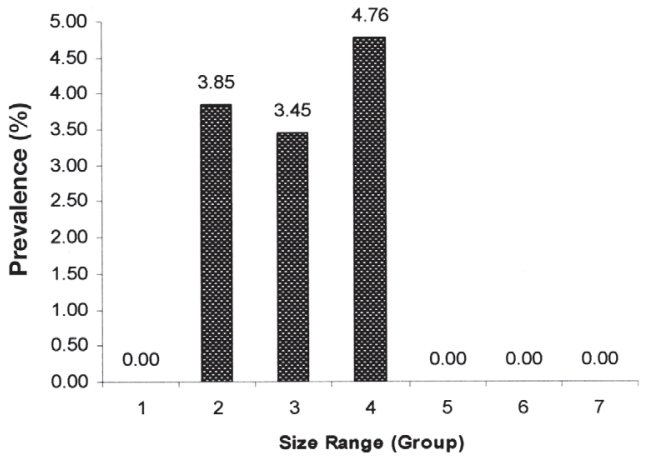

Fig. 2G. Prevalence of Oxyuris * Size.

to $P$. awokoyai, Capillaria sp. and $O$. agamae (Fig. 3B). Intensity of Oxyuris sp. infection was the same in both male and female lizards (Fig. 3B). There were no significant differences in the prevalence of individual parasites and the
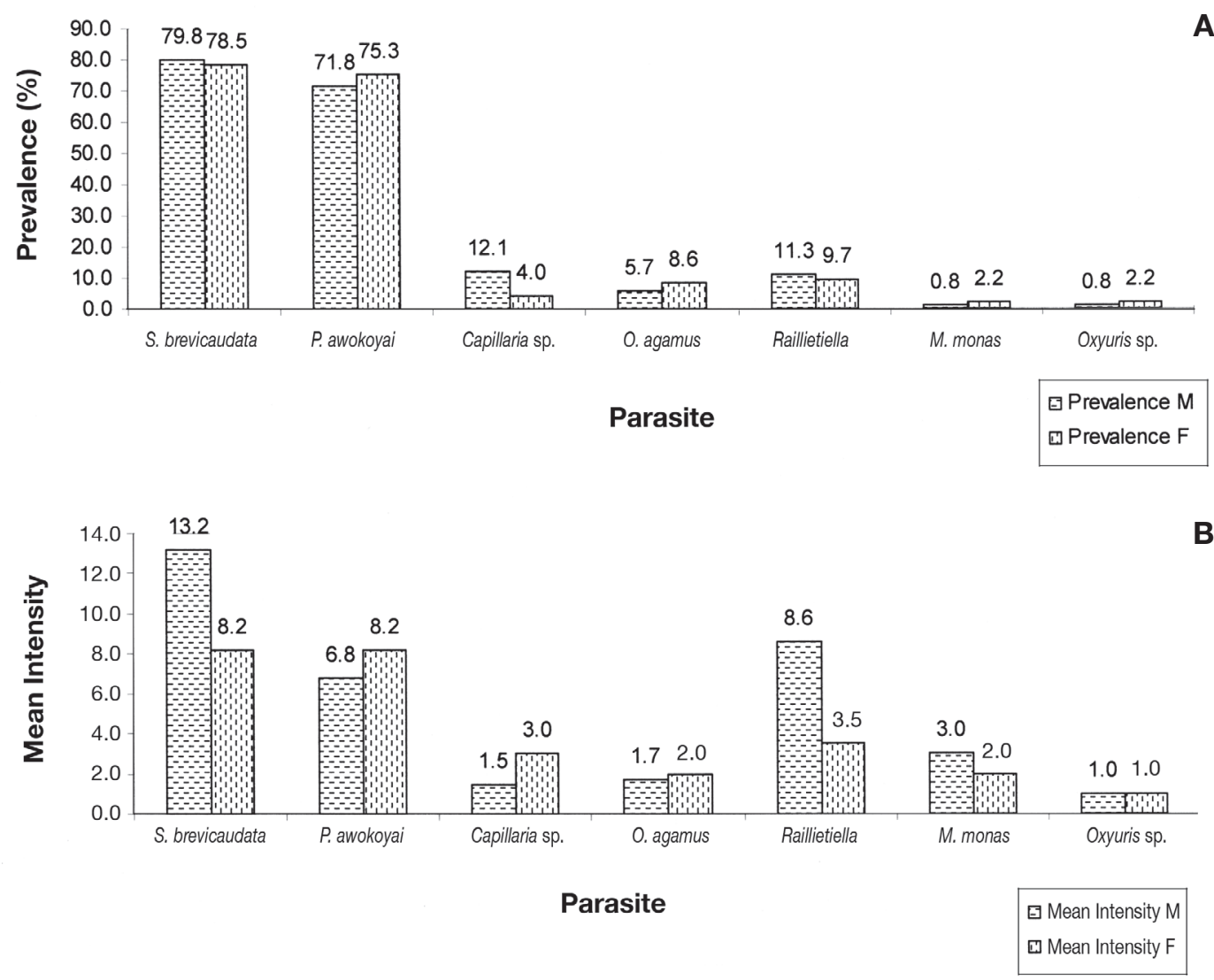

Fig. 3. A. Prevalence of infection in relation sex. B. Mean intensity of parasites in relation to sex. 
sex of lizards examined ( $>00.05$ ). However, there were significant differences in the overall intensity of parasites and the sex of lizards $(\mathrm{p}<0.05)$.

S. brevicaudata and P. awokoyai, had highest prevalence and mean intensity in the three months of study. M. monas and Oxyuris sp. were generally found to have the lowest values for prevalence and mean intensity across the three months. Overall, the highest prevalence of infection by $S$. brevicaudata, $P$. awokoyai and Raillietiella sp. (92.0\%, 84.0\% and $15 \%$ respectively) was observed in June; Capillaria sp. (15\%), O. agamae (9 \%), M. monas (4 $\%$ ) and Oxyuris sp. (3\%) in July, and no peak prevalence for any of the parasites in May. However, mean intensities of Capillaria sp. and $M$. monodi were highest in May, S. brevicaudata and P. awokoyai in June, Raillietiella sp. and O. agamae in July. Oxyuris had equal mean intensities in May and July. The prevalence and mean intensity of helminthes recovered from the lizards varied significantly with the month of collection (both $\mathrm{p}<0.05$ ).

\section{DISCUSSION}

Of the seven parasite species recovered, nematodes, especially $S$. brevicaudata and $P$. awokoyai, were the most prevalent. No acanthocephalan was discovered during the course of study. In an investigation of reptile species by Borkovcova and Kopriva (2005), of the twelve parasites found, nematodes occurred most often, followed by trematodes and cestodes; no acanthocephalans were also detected. High diversity in helminth infra-communities was shown to be due to the large size, wideranging plant diet and exposure to helminthes with direct life cycles (Martin and Rocha 2004). Helminth acquisition thus appears to be related with the diet of saurian reptiles (Sanchis et al. 2000).

According to the findings of this study, male lizards, being the more active sex, had a higher level of intensity of infection than female conspecifics. The difference was statistically significant between intensity of infection and sex. The difference between prevalence in male lizards and female lizards was small. An insignificant difference between intensity and prevalence in sexes was recorded in a research conducted by Fadiel et al. 2005. An interesting report by Amo et al. (2005) stated that males and females seem to be similarly susceptible to parasite's infection, as the prevalence and intensity of infection were similar in both sexes. Similar studies in lizards (Uller and Olsson 2003) and other organisms have found that males are more susceptible to parasite's infection probably due to the immune suppressive effects of testosterone, at least during the reproductive period (Roberts et al. 2004). Early in the mating period, males maintain high levels of testosterone hormone (Tokarz et al. 1998), which makes them more aggressive, thus more able to obtain and maintain a territory. In pregnant females, the development of eggs requires a great amount of energy and metabolites, which could not be allocated to defense against parasites. Therefore, both sexes seem to invest more in reproduction than in defense against parasites (Amo et al. 2005).

The most infected organ, in this study, was found to be the rectum, harboring four species of parasites. This is due to the fact that endoparasites seek places in the host that provide maximum nutritional value to it. The rectum, filled with undigested food, serves as a convenient habitat for nematodes; bloodsucking pentastomids were found in the lungs, and the intestine was the organ of choice for cestodes which feed on digested food. Two species, Capillaria and Oxyuris were recovered from the stomach, being able to withstand the acidic condition and the digestive juices present. S. brevicaudata and $P$. awokoyai preferred the more alkaline condition of the intestine and the rectum. The lumen of the rectum is wider, thus a large number can survive inside it. Cestodes tend to block the already narrow intestine due to their length, thus reducing the carrying capacity of the intestine of the lizards; hence, low worm burden of cestodes. Statistical analysis showed that the difference between 
number of parasites and organs of the lizards were significant. There was also significant difference between species found and the organ, showing that parasites are usually organ-specific. Therefore, the organ in which the parasite resides, aids in determining the intensity of infection. The difference between the number of parasites and the type of parasites was also statistically significant.

Size of lizard was used as a direct measurement of age. From these findings, lizards within the size range of $10.0 \mathrm{~cm}$ and $13.9 \mathrm{~cm}$ were the most parasitized. The minimum SVL for the infected lizards was $8.4 \mathrm{~cm}$. There was significant difference between the SVL of lizards and the number of parasites, implying that the older the lizard host, and the higher intensity of infection. Mean intensity of infection, on the whole, was found to be highest in lizards with lengths within $9.0-9.9 \mathrm{~cm}$ and $13.0-13.9 \mathrm{~cm}$, coinciding with the size of a majority of the adult females and males respectively. This agrees with the findings of Ribas et al. (1995) and Amo et al. (2005), where prevalence of infection by helminthes was positively correlated with the adult size of the lizards they studied. Adults were expected to be more infected because they occupy, more frequently, the more favorable places such as basking spots or refuges, and they interact more with other adults, exposing them to vectors and also because older lizards supposedly had more time/probability to get contact with the parasites, compared to youngs. On the other hand, younger ones are often limited to suboptimal areas by dominant older male lizards. Ribas et al. (1995) also showed that the total mass of nematodes increased significantly with lizard body size. Results also imply that there is no immunity to infection as they grow older. However, infection rate was not significantly influenced by host body size in an investigation of a partenogenetic whiptail lizard (Cnemidophorus nativo) (Menezes et al. 2004). Generally, life span of lizards is between five to 20 years.

Significant differences were observed in the prevalence of infection in the three months of study (May-July 2005), in both sexes. There was no significant difference in their mean intensities. This suggests that the amount of rainfall plays a role in determining the presence and number of parasite transmission stages or encysted forms (in parasites with a direct life cycle), or its vector (in parasites with an indirect life cycle), within the habitat of the host. The months of May, June and July fall within the wet season in Nigeria. The breeding season of A. agama is all year-round in rainforest belt, but in drier savanna regions, breeding season coincides with the rainy season (Harris 1964). During this study, the heaviest rain was experienced in the month of May, and the lowest in June. Raillietiella sp. was observed to have high intensity in May in both sexes, which reduced by June to increase again in July to its highest peak in males, but further reduced in the females. These differences in intensity could be explained by observing the structure of the egg, which is covered by two distinct transparent and inelastic membranes, $115 \times 88$ microns, making them weather-tolerant (Esslinger 1968). On the other hand, $P$. awokoyai had a steady decrease in mean intensity and prevalence across the three months. $S$. brevicaudata had its highest mean intensities in the month of July, and generally had relatively high mean intensity and prevalence across the three months. These parasites seem to have been better adapted to the seasons and are not affected by type of season. Eggs of $S$. brevicaudata are thick-shelled, containing embryos at deposition (Yamaguti 1961). In one study, the prevalence of a nematode, Spauligodon hemidactylus was significantly higher in the rainy season than in the dry season (Matsuo and Oku 2002). There were no monthly differences in the prevalence or intensity of infection in adults examined by Amo et al. (2005). They suggested that infections occurred early in the breeding season, when lizards were more active. The body condition of Lacerta lepida decreased during the mating period (that is, the wet season), reproductive activities led to a decrease in the body condition; however, intensity of infection did not affect the body condition of lizards (Amo et al. 2005). 
We concluded that seven species of helminthes and prevalence was found to be higher in lizards with longer SVL, thus the older the lizard, the higher the level of infection. Findings also indicate that the species of parasite present determines the number of parasites found, which in turn determines the intensity of parasitic infection.

\section{ACKNOWLEDGMENTS}

We appreciate the efforts of Dapo Kola Olowo, Lanre Ola and Nnamdi Amaeze, who assisted in the collection of the lizards. Special thanks also to A. Oworu for providing technical assistance.

\section{RESUMEN}

La lagartija Agama agama actúa como medio de transporte y hospedero para varios protozoos y helmintos parásitos. Capturamos 310 lagartijas, muestreadas aleatoriamente, entre mayo y julio 2005, en Oyingbo, Lagos, Nigeria (6 $34^{\prime} 60^{\prime \prime} \mathrm{N}-3^{\circ} 19^{\prime} 59^{\prime \prime}$ E y 6 $34^{\prime} 60^{\prime \prime} \mathrm{N}-3^{\circ} 19^{\prime} 59^{\prime}$ " E). Hallamos cuatro especies de nematodos: Strongyluris brevicaudata, Parapharyngodon awokoyai, Capillaria y Oxyuris; un céstodo intestinal, Oochoristica agamae; un trematodo, Mesocoelium monodi; y un pentastómido, Raillietiella. S. brevicaudata tuvo la mayor prevalencia de infección (82.26\%), seguida por P. awokoyai (74.52\%), Raillietiella (10.32\%), Capillaria $(8.38 \%)$ у O. agamae (7.41\%). M. monodi y Oxyuris tuvieron baja prevalencia con $1.61 \%$ cada uno. Raillietiella y Capillaria causan inflamación localizada e infección intestinal en humanos. La prevalencia de infección estuvo positivamente relacionada con el tamaño de las lagartijas adultas. Los machos tuvieron mayor prevalencia, con $97.58 \%$ (hembras 94.09 $\%$ ). La infección intestinal en los machos fue mayor para cuatro de las especies de helmintos. La intensidad parasitaria fue mayor en el recto, seguida por el intestino $(\mathrm{p}<0.05)$. La intensidad de la infección fue dependiente del tipo de parásito y la edad de la lagartija. En mayo, P. awokoyai tuvo el mayor promedio de intensidad y prevalencia. La prevalencia y la intensidad promedio de $S$. brevicaudata fue mayor en junio (julio en las demás especies). La prevalencia y la intensidad variaron con el mes (ambos $\mathrm{p}<0.05$ ).

Palabras claves: helmintos intestinales, Agama agama, prevalencia, intensidad, Nigeria.

\section{REFERENCES}

Akinboade, O.A. \& O.O. Dipeolu. 1982. Studies on Parasites of African Snakes. Zoonoses 9: 87-89.

Ameh, I.G. \& J.A. Ajayi. 1996. A gregarinian parasite of the wall gecko. Nigerian J. Parasitol. 17: 121-123.

Amo, L., J.A. Fargallo, J. Martinez-Padilla, Millán, P. López \& J. Martin 2005. Prevalence and intensity of blood and intestinal parasites in a field population of a Mediterranean lizard, Lacerta lepida. Parasitol. Res. 96: 413-417.

Babero, B.B. \& I. Okpala. 1962. Parasites of the Lizard, Agama colonarum, in Nigeria with description of new species. Trans. Am. Micros. Soc. 81: 61-62.

Borkovcova, M. \& J. Kopriva. 2005. Parasitic Helminthes of Reptiles (Reptilia) in South Moravia (Czech Republic). Parasitol. Res. 95: 77-78.

Bush, A.O., K.D.Lafferty, J.M. Lotz, \& A.W.Shostak. 1997. Parasitology meets ecology in its own terms: Margolis et al. revisited. J. Parasitol. 83: 575-583.

Esslinger, J.H. 1968. Morphology of the Egg and Larva of Rallietiella furcocerca (Pentastomida) From A Colombian Snake (Clelia clelia). J. Parasitol. 54: 411-416.

Fadiel, M.M., H.M.S. Ibrahim \& G.A. Nair. 2005. Gastrointestinal Helminthes of the Lizard, Chalcides ocellatus, from Benghazi, Libya. J. Helminthol. 79: 35-39.

Harris, V.A. 1964. The Life of the Rainbow Lizard. Hutchinson Tropical Monographs, London, England. 174 p.

Martin, J.E. \& V. Roca. 2004. Helminth Infracommunities of a Population of the Gran Canaria Giant Lizard, Gallotia stehlini. J. Helminthol. 78: 319-322.

Matsuo, K. \& Y. Oku. 2002. Endoparasites of the three species of House Geckoes in Lampung, Indonesia. J. Helminthol. 76: 53-57.

Menezes, V.A., D. Vrcibradic, J.J. Vicente, G.F. Dutra \& C.F.D. Rocha. 2004. Helminthes infecting the Parthenogenetic Whiptail Lizard, Cnemidophorus nativo, in a resting Habitat of Bahia State, Brazil. J. Helminthol. 78: 323-328.

Olsen, O.W. 1974. Phylum Nemathelminthes. Animal Parasites- Their Life Cycles and Ecology. University Park, Baltimore, Maryland, USA. 562 p. 
Ribas, S.C., C.F.D. Rocha, P.F. Teixeira-Filho \& J. Vicente. 1995. Helminths (Nematoda) of the lizard Cnemidophorus ocellifer (Sauria: Teiidae): Assessing the effect of rainfall, Body size and sex in the nematode infection rates. Cien. Cult. 47: 88-91.

Roberts, M.L., K. Buchanan \& M. Evans. 2004. Testing the immunocompetence-handicap hypothesis: a review of evidence. Animal Beh. 68: 227-239.

Sanchis, V., J. Roig, M. Carretero, V. Roca \& G. Llorente. 2000. Host-parasite relationships of Zootoca vivipara (Sauria: Lacertidae) in the Pyrenees (North Spain). Parasitol. 47: 118-122.

Tokarz, R.R., S. Mcmann, L. Seitz \& H. John-Alder. 1998. Plasma corticosterone and testosterone levels during the annual reproductive cycle of male brown anoles (Anolis sagrei). Physiol. Zool. 71: 139-146.

Uller, T. \& M. Olsson. 2003. Prenatal exposure to testosterone increases ectoparasite susceptibility in the common lizard (Lacerta vivipara). Proc. R. Soc. London. 270: $1867-1870$.

Wardle R.A. \& J. McLeod. 1968. The Zoology of Tapeworms. Hafner, New York, USA. 781 p.
Webb, J.E., J. Wallwork \& J. Elgood. 1976. Guide to Living Reptiles. Macmillan, London, England. 172 p.

Webb, J.E., J. Wallwork \& J. Elgood. 1978. Tardigrades and Pentastomids. Guide to Invertebrate Animals. Macmillan, London, England. 305 p.

Wekhe, S. N. \& F.O. Olayinka. 1999. The role of Agama agama in the transmission of coccidiosis in poultry. Nigerian Vet. J. 20: 34-36.

Yamaguti, S. 1961. Nematode of Reptiles. Systema Helminthum, Volume 3. Interscience, New York, USA. 1261 p.

\section{INTERNET REFERENCES}

Nash, H. 2005. Pentastomes: Respiratory Parasites of Reptiles. Veterinary Services Department, Drs. Foster \& Smith, city, country (http://www.peteducation.com/article.cfm?cls $=17 \&$ cat $=1831 \&$ articleid $=27$ 54. Downloaded: 1-XII-2006)

The Weather Underground. 2006. Lagos Nigeria Forecast. Incity, country. (http://www.wunderground.com/history/airport/DNMM/2005/MonthlyHistory.html. Downloaded: 1-XII-2006) 
